Review scientific article Received 29.04.2019. Approved 26.07.2019.

\title{
PERFORMANCE INDICATORS AND THE POSSIBILITY OF APPLICATION OF BALANCED SCORECARD IN HIGHER EDUCATION INSTITUTIONS
}

The application of exploratory and descriptive research at working points to the importance and the possibility of applying Balanced Scorecard in higher education institutions. The aim is to highlight good practice of implementation of the Balanced Scorecard in higher education and proposing performance indicators for each of the perspectives at the level of higher education institutions which could be used for monitoring and measuring the impact of higher educational institutions in Serbia. The proposed indicators are of a general nature and can be applied in any higher education institution, especially in developing countries in the context of the reform and development of a higher education system. The results of the research show the presence of performance indicators of higher educational institutions in the educational system of Serbia. They can be recognized in documents at the national level. They just have to be improved in terms of uniformity and universality.

Keywords: Balanced Scorecard, Performance Indicators, Higher Education, Strategy.

Belgrade Polytechnic, Faculty of Organizational Sciences, Belgrade, Sebia;

drosulj@politehnika.edu.rs

** Faculty of Organizational Sciences, University of Belgrade, Serbia; petrovic.dejan@fon.bg.ac.rs 


\section{Introduction}

Higher education reforms imposed the need for the establishment of a strategic management system in higher education institutions (HEI) that allows monitoring, measuring, analyzing and improving overall performance and reviewing them in terms of mission, vision, policy, strategy, and goals at all levels and all processes in an institution.

In accordance with the previous, the Balanced Scorecard (BSC) provides a good response because it represents a performance management system that transforms the defined strategy into performance indicators (goals) and concrete activities that should lead to the realization of these objectives through four balanced perspectives (financial perspective, the perspective of users, the perspective of business processes and the development perspective).

Strategy and strategically oriented management are emphasized in terms of achieving desired performance and in the context of a competitive position in the higher education market.

By analyzing the relevant and available literature, the paper highlights the importance and benefits of the BSC as a systemic performance management solution at the strategic level, with particular reference to demonstrating the possibility of its application in the HEI.

The main objective is to express the importance, possibilities, and benefits of applying the BSC in the HEI, as well as proposing performance indicators for each of the BSC perspectives characteristic of higher education. The proposed indicators would create an environment for raising awareness about the ability to measure the performance of the HEI and encourage the implementation of the BSC for that purpose.

\section{Methodology and methods of research}

Insufficient research on the parameters of strategic management in the field of higher education in our area, as well as the insufficient exploration of the application of the BSC in higher educational institutions, influenced the creation of an idea for exploring the mentioned topic.

The basic method of research is based on existing theoretical results and examples of good practice of BSC in higher educational institutions. The research methodology is based on the collection and study of available literature, its analysis, and systematization, with the aim of demonstrating the importance, justification, and usefulness of applying the BSC in a higher educational institution.

Regarding the type of research, exploratory and descriptive research was applied in this document. During the exploratory research, and in order to perceive strategic management in higher education in higher educational institu- 
tions, relevant literature related to strategic management was used. The experiences and practices that exist in these higer institutions of educational systems of other countries, which have implemented the BSC to a certain extent, as well as publications available through the search of scientific and professional journals and index databases, have also been used. To search for publications in electronic journals, the following keywords were used: BSC, higher education institutions, strategy, performance indicators and performance. Regarding the time period, the research included published works in the last 10 years. In the usage of relevant literature, publications related to the application of the BSC in higher education institutions, as well as publications related to the application of the BSC in the private and public sector, to the strategy and performance of higher education institutions have been prioritized.

Currently, a relatively small number of scientific and professional papers on the topic of usage of BSC in higher education institutions and in general the use of strategic management systems in the field of education in the country and the region are available in domestic literature. There is a particularly small amount of research on the subject of the BSC, in terms of the methodological approach and the result of its implementation, which is one of the additional motives for this research. The main purpose of this research is to point out, on the basis of the applied methodology, the possibilities, and advantages of applying the BSC in higher education institutions and to suggest performance indicators applicable to all higher education institutions.

\section{Balanced Scorecard}

\subsection{General about Balanced Scorecard and its application in higher education institutions}

Balanced Scorecard is defined as a management system by which the organization translates its vision and strategy into concrete goals. It also provides feedback on the ongoing activities to continuously improve the implementation of the strategy ${ }^{1}$.

It is precisely the most common problems in strategic management that occur in the process of strategy implementation, rather than in its formulation. That is why the BSC was primarily created as a mechanism for the implementation of the strategy, its formulation ${ }^{2}$.

Jovanović Petar (2007):Strategijski menadzment. Beograd. Fakultet organizacionih nauka. 158. Kaplan S. Robert, Norton P.David (1996): The Balanced Scorecard: Translating Strategy into Action. Harvard Business School Press, Boston, Massachusetts. 10. 
The original idea of the BSC comes from the need for a performance measurement model that does not focus only on financial indicators, but also focuses on non-financial indicators such as intellectual property ${ }^{3}$.

At the very beginning, BSC has been developed as a performance measurement model that allows management to see an organization from various perspectives, such as: learning and growth perspective, perspective of internal processes, customer perspective, and financial perspective. However, Kaplan and Norton recognize that performance measurement should start from the organization's strategy and indicate that effective measurement must be an integral part of the organization's strategy ${ }^{4}$.

BSC is much more than the method used to measure the performance of an organization ${ }^{5}$. Current modern organizations apply the BSC as a strategic management system. Thus, BSC from the performance measurement system ${ }^{6}$ switched to a business strategic management system ${ }^{7}$.

\section{Figure 1: Balanced Scorecard structure}

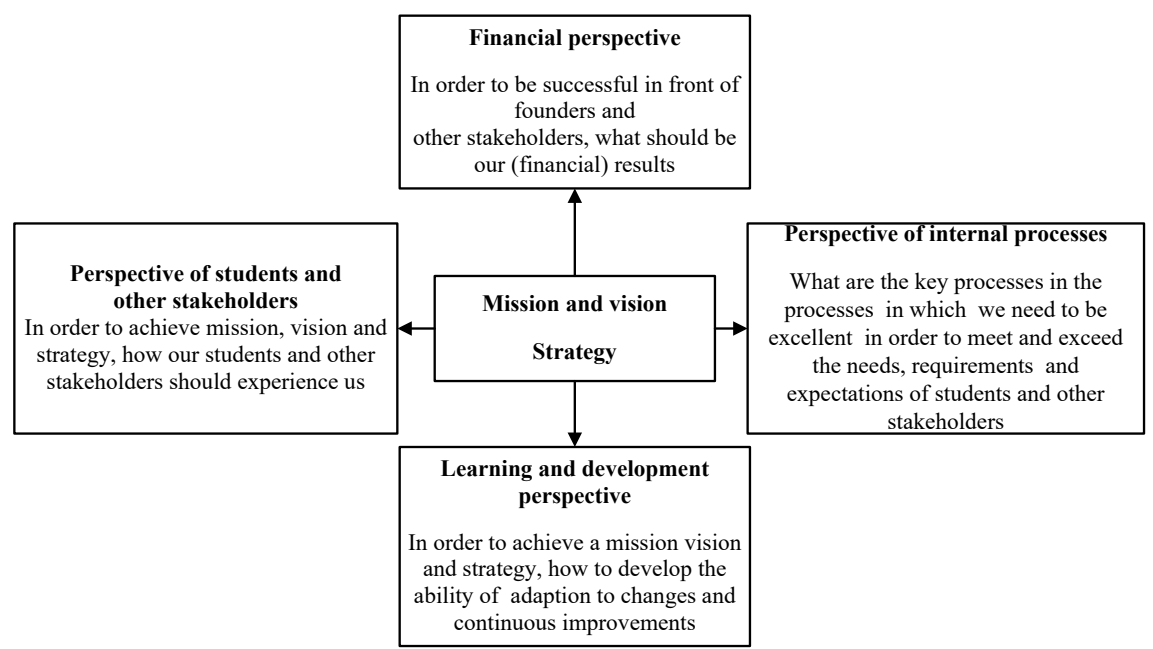

Source: Kaplan S. Robert., Norton P.David (1996): The Balanced Scorecard: Translating Strategy into Action. Harvard Business School Press, Boston, Massachusetts.

3 Sudirman Indrianty (2012): Implementing Balanced Scorecard in Higher Education Management. Case Study: Hasanuddin University of Indonesia. International Journal of Business and Social Science, Vol.3. No.18. 200.

$4 \quad$ Kaplan S. Robert, Norton P.David (1993): Putting the Balanced Scorecard to Work, Harvard Bussiness Review.2.

$5 \quad$ Kaplan S. Robert., Norton P.David (1996),10.

$6 \quad$ Kaplan S. Robert, Norton P.David (1992): The Balanced Scorecard - Measures that Drive Performance. Harvard Business Review. 71.

$7 \quad$ Kaplan S. Robert., Norton P.David (1996). 2. 
The structure and content of the BSC are shown in Figure 1. BSC retains financial measures, but simultaneously focuses its attention to three additional perspectives - users, internal processes, learning, and development - which represent long-term initiators of competitive advantage and success of a higher education institution ${ }^{8}$.

BSC through certain indicators in any organization, the same as in the higher education institution, monitors how successful the strategy is. All four perspectives are establishing a system of indicators, whose analysis enables the monitoring and evaluation of the success of the business strategy ${ }^{9}$. Indicators enable monitoring of the process of realization of goals and strategies, i.e. allows the organization to monitor whether it stays on the right path ${ }^{10}$.

In each of the four perspectives, strategic goals and measures for the realization of these goals are defined. Each of the goals has one or more indicators that show the degree of goal realization. These values are indicators of causes and consequences. The indicators of consequences describe the results of the implemented activities. The indicators of the causes give information on how the strategy is being implemented and warns on time, whether the strategy takes place in accordance with the plan. That allows corrective measures to be taken on time to return the process of implementation of the strategy to the planned frameworks. By the time the BSC shows the ability of monitoring and controlling the implementation of the strategy, which is one of the greatest importance for the strategic management of the organization. ${ }^{11}$

By analyzing the literature, it can be seen that BSC has wide application in various areas of governance, in the private and public sectors, as well as in the developed and the developing countries.

Authors Chen, Beasley \& Nunez, point out the connection between BSC and risk management. According to the same authors, BSC and risk management in the organization have many common elements. The common elements of these two systems are strategy orientation, holistic approach, emphasis on leadership (both systems are guided by the top of the organization), consistency, focus on responsibilities, continuity. The implemented BSC system in the organization provides a unique basis for obtaining the benefits of risk management. The authors also point out that the use of indicators from the BSC in risk management leads to the expansion of the risk management focus, i.e. the scope of risk management is expanded and linked to strategic performance measurement. ${ }^{12}$

Kaplan S. Robert., Norton P.David (1996). 10.

Jovanović Petar (2007), 158.

10 Jaško Ondrej, et al. (2013): Projektovanje organizacije. Beograd. Fakultet organizacionih nauka. 378.

11 Jovanović Petar (2007), 160.

12 Chen S. Al Yuang, Beasley Mark, Nunez Karon (2006): Working Hand in Hand: Balanced Scorecard and Enterprise Risk Management. Strategic Finance. 51. 
When it comes to BSC's impact on costs, the authors Geuser, Moore \& Oyon indicate that it is difficult to estimate them in advance because of the multiple benefits that result from its application, which are seen only after a long period of application. An additional reason is that some of the benefits cannot be clearly expressed in terms of material but remain hidden under opportunistic costs. But, within the research of the same authors, respondents ${ }^{13}$ consider that the benefits of BSC exceed the costs of its implementation.

In terms of BSC's impact on financial performance, the results of the research by Sweiti \& Lele show that BSC has a significant impact on income growth, but when it comes to Net Margin, Current Ratio and Operating Cash Flow/Net Income has no significant impact ${ }^{14}$.

Sulanjaku in his paper points to the possibility of applying BSC in the measurement and management of intangible assets in economic organizations of Albania. The author concludes that the application of the BSC can certainly help the management to better manage the intangible assets. When it comes to the case of Albania, the author believes that it is still early in the implementation of such a system, due to the lack of employee experience and the cost of its implementation ${ }^{15}$.

Visalakshi (2016) in his dissertation proposes the application of the BSC to measure performance in commercial banks in India ${ }^{16}$. Manica and other authors describe in detail the BSC implementation process in the technology organization in Brazil. They conclude that the organization is aware of the importance of the BSC because through its implementation it includes all parts of the organization and increases the visibility of the objectives to be achieved, as well as the degree of their realization ${ }^{17}$.

Luo \& Zeng write about the application of the BSC in China. They point out that the application of this system in China began much later than in other Western countries and that its implementation contends with a lot of obstacles. The authors explore what happened to the BSC in the West and what are the problems

13 Geuser D. Fabien, Mooraj Stella, Oyon Daniel (2009): Does the Balanced Scorecard Add Value? Empirical Evidence on its Effect on Performance. European Accounting Review. Vol.18. No.1. 109.

14 Sweiti M. Ibrahim, Lele Upendra (2016): Impact of Balanced Scorecard Implementation on Financial Performance of Saudi Listed Companies. Journal of Behavioural Economics, Finance, Entrepreneurship, Accounting and Transport. Vol. 4. No. 1. 8-12.

15 Sulanjaku Marsel (2014): The Perspecives of Using Balanced Scorecard in Intangibles Measurement and Management in Albania. International Journal of Managerial Studies and Research. Vol 2. No 9. 132-139.

16 Visalakshi, S. (2016): Performance measurement of Commercial Banks in India using Balanced Scorecard. School of Management. Pondicherry University. Pondicherry. (PhD thesis).

17 Manica Edson et al. (2017): Deployment of the Balanced Scorecard as A Tool for Measuring Performance: The Case of A Technology Company in Brazil. Business Management Dynamics. Vol.7, No.6, 8-18. 
and limitations in its implementation, what are the barriers to its application in China, and give recommendations for its implementation. They also want to point out that it's time to explore the possibility of using BSC in developing economies ${ }^{18}$.

Gao et al. pointing to the possibility of using BSC for the needs of evaluating the performance of hospitals in underdeveloped regions of China. According to this group of authors, the efficiency of the use of resources, the cost of medical services, the staff structure and the relation between the doctor and the patient are indicators that affect on the performance of the hospital ${ }^{19}$.

The problem and perspective of the implementation of BSC in Serbia are reviewed by authors Domanovic, Bogicevic, Savovic. Based on the analysis of a small number of reputable companies in Serbia, they generally conclude that a very small number or even one company has not implemented the BSC as explained in the literature, or as implemented by companies in other countries ${ }^{20}$. Authors Tornjanski, Knezevic and Delibasic applied the BSC system to identify and develop the main financial and non-financial indicators within the banking sector in order to raise the level of relationship management with customers ${ }^{21}$.

Pravdic points out that there is still not enough developed awareness in Serbia about the usefulness of the BSC, especially for the public sector and commercial organizations ${ }^{22}$. Authors Todorovic, Kalicanin and Nojkovic in their research on the practice of measuring performance in organizations in the Republic of Serbia (RS) concluded that the BSC as a system is present in organizations in the RS, much more in large organizations than in small organizations. They also conclude that the BSC is more represented in organizations with internationalized operations ${ }^{23}$.

Today, we are talking about the innovated BSC concept called "Sustainability Balanced Scorecard (SBSC)”. The concept is the result of a research carried out by scientists from the Institute of Economics and the Environment in St. Gallen and the University of Luneburg.

$18 \quad$ Zeng Kaisheng, Luo Xiaohui (2013): The Balanced Scorecard in China: Does it work? Business Horizons. 56. 611-620.

19 Gao Hongda, et al. (2018): Balanced scorecard-based performance evaluation of Chinese county hospitals in underdeveloped areas. Journal of International Medical Research. Vol. 46(5). 1947-1962.

20 Domanović Violeta, Bogićević Jasmina, Savović Sladjana (2012): Problems and Perspectives of Balanced Scorecard Implementation in Serbia. African Journal of Business Management. Vol. 6(23). 6818-6831.

21 Tornjanski Vesna, Knežević Snežana, Delibašić Boris (2016): A CRM Performance Measurement in Banking Using Integrated BSC and Customized ANP-BOCR Approach. Management: Journal of Sustainable Business and Management Solutions in Emerging Economies. Vol. 22. No.1. 71-85.

22 Pravdić Predrag (2011): Spreading BSC Idea and Technology in Serbia. 38. Nacionalna konferencija o kvalitetu. Festival kvaliteta - FQ2011. 21-28.

23 Todorović Miroslav, Kaličanin Djordje, Nojković Aleksandar (2015): Prakse merenja performansi u preduzećima u Republici Srbiji. Ekonomski horizonti. Vol.17. (1). 45-59. 
The standard BSC is focused on implementing the strategy at the operational level through key performance indicators within four areas, while an innovative BSC concept focuses on strategy in the long term through three different perspectives: economy, ecology and society. Sustainable BSC helps organizations in defining strategies related to social, ecological and economic goals ${ }^{24}$.

In accordance with the aforementioned, Kalender in his paper writes about sustainability as the fifth pillar of the BSC, which would provide organizations with a better insight into all factors of business. Sustainable BSC based on the traditional BSC is focused on better-performing aspects of business, and as such provides a wider scope integrating all three dimensions of sustainability. According to the same author, this perspective consists of social, ecological and economic indicators that measure the organization's performance in terms of sustainability ${ }^{25}$.

There are several ways to include aspects of sustainability in BSC. Redesigning existing cards is one way. Adding key new perspectives is another way, and the third can be the formulation of special cards that relate to the ecological and social aspect ${ }^{26}$.

Al-Zwyalif proposes an ecological BSC model (EBSC) in his paper. The proposed model, through all four perspectives of the standard BSC, contains aspects of the environment. In addition to serving as an environmental performance assessment, it can also serve to raise environmental awareness and to implement ecological sustainability ${ }^{27}$.

When it comes to the implementation and application of the BSC in higher education institutions, different examples can be found in the literature, while in Serbia its application is still not at an enviable level.

Eftimov et al. propose the process of designing BSC in higher education (Macedonia case) through six steps, starting from defining a vision, through defining a mission, translating the mission into strategic goals, defining a strategy for achieving those goals, creating a strategic map to the very design of the system. They also provide a proposal of targets and key performance indicators for all four perspectives. They have suggested about 100 indicators for all four perspectives, but recommend that it is necessary to choose for each perspective about 5-6 indicators. They conclude that for the Faculty of Economics - Skopje

24 Sustainbality Balanced Scorecard, BSC Designer: https://bscdesigner.com/sustainabilitybalanced-scorecard-sbsc.htm (pristupljeno 17.06.2018.)

25 Kalender T. Zeynep (2016): The Fifth Pillar of the Balanced Scorecard: Sustainability. Procedia - Social and Behavioral Sciences.Vol. 235. (24).80.

26 Stevanović Tatjana, Petrović - Randjelović Marija (2012): Sustainability Balanced Scorecard and Eco-efficiency Analysis. Economics and Organization. Vol 9. No 2.263.

27 Al-Zwyalif M. Inaam (2017): Using a Balanced Scorecard Approach to Measure Environmental Performance: A Proposed Model. International Journal of Economics and Finance; Vol. 9, No. 8. 118-126. 
in the process of monitoring the success of faculties, the best solution are the 30 designated indicators ${ }^{28}$.

Pimentel and Major write about quality management and BSC in support of management and organizational changes ${ }^{29}$. Wahba writes about the application of BSC access at the private Arab Academy for Science, Technology and Maritime Transfer. ${ }^{30}$ Umashankar and Dutta discuss the application of the BSC in the Indian context ${ }^{31}$. Chalaries, Chalaries and Gritzalis discusses the application of the BSC as a holistic approach to quality assurance and improvement of decision-making processes in educational institutions ${ }^{32}$.

Pietrzak, Paliszkiewicz and Klepacki speak about the application of the BSC at the Polish University ${ }^{33}$. Deshpande points to the possibility of applying BSC in higher education with a special focus on business schools ${ }^{34}$. Binden, Mziu, Suhaimi point to the application of the BSC for performance measurement in higher education institutions in Malaysia ${ }^{35}$.

Based on these sources, the paper shows how much BSC has wide application in different countries of the world. In addition, the theoretical basis for its application is provided at higher education institutions in Serbia.

A defined strategy needs to be translated into goals. The method of communication that indicates what has to happen to improve the circumstances for the

28 Eftimov Ljupco, et al. (2016): Designing a Balanced Scorecard as Strategic Management System for Higher Education Institutions: A Case Study in Macedonia. Ekonomika: Vol. 62. No. 2. 29-48.

29 Pimentel Luis, Major J. Maria (2014): Quality management and a balanced scorecard as supporting frameworks for a new management model and organisational change. Total Quality Management. Vol. 25( 7). 763-775.

30 Wahba Mohamed (2016): Balanced Scorecard in Higher Education Applied case study on "Arab Academy for Science, Technology and Maritime Transfer. International Journal of Scientific Research and Innovative Technology. Vol. 3. No. 5. 69-91.

31 Umashankar Venkatesh, Dutta Kirti (2007): Balanced Scorecards in managing higher education institutions: an Indian perspective. International Journal of Education Management. Vol. 21(1). 54-67.

32 Chalaris Ioannis, Chalaris Manolis, Gritzalis Stefanos (2014, October):.A holistic approach for quality assurance and advanced decision making for academic institutions using the balanced scorecard technique. PDI 14 - Proceedings of the $18^{\text {th }}$ Panhellenic Conference on Informatics. 1-6.

33 Pietrzak Michail, Paliszkiewicz Joanna, Klepački Bogdan (2015): The application of the balanced scorecard (BSC) in the higher education setting of a Polish university. Online Journal of Applied Knowledge Management. Vol.3(1). 151-164.

34 Deshpande Bharati (2015, March): Application of Balanced Score Card in Higher Education with special emphasis in a Business School. International Conference on Technology and Business Management. 201-205.

35 Binden Worawit, Mziu Hajdar, Suhaimi Mohd Adam (2014): Employing the Balanced Scorecard (BSC) to Measure Performance in Higher Education - Malaysia. International Journal of Information and Communication Technology Research, 4(1). 38-44. 
realization of the defined strategy is a strategic map. The strategic map indicates what is to be done well in each of the four perspectives, in order to achieve the ultimate goals ${ }^{36}$. Using several different sources in Figure 2, he illustrated how a strategic map for higher education institutions could be displayed.

The Strategic Map graphically describes the process of creating value through a series of cause and effect relationships between indicators within all four perspectives of the BSC. The arrows and fields on the map show the goals that all employees in the higher education institution need to focus on in order to achieve the strategy. Each field represents a key performance indicator and arrows cause and effect relationships that exist in the process of creating value ${ }^{37}$.

For each of the BSC, perspectives are defined strategic goals and performance indicators that related to these goals, as well as the way of measuring results. The higher education institutions should define the indicators in accordance with the adopted strategic objectives at the institution level, as well as the possibilities to apply the results obtained on the basis of the defined indicators.

\section{Figure 2: Strategic map for education service}

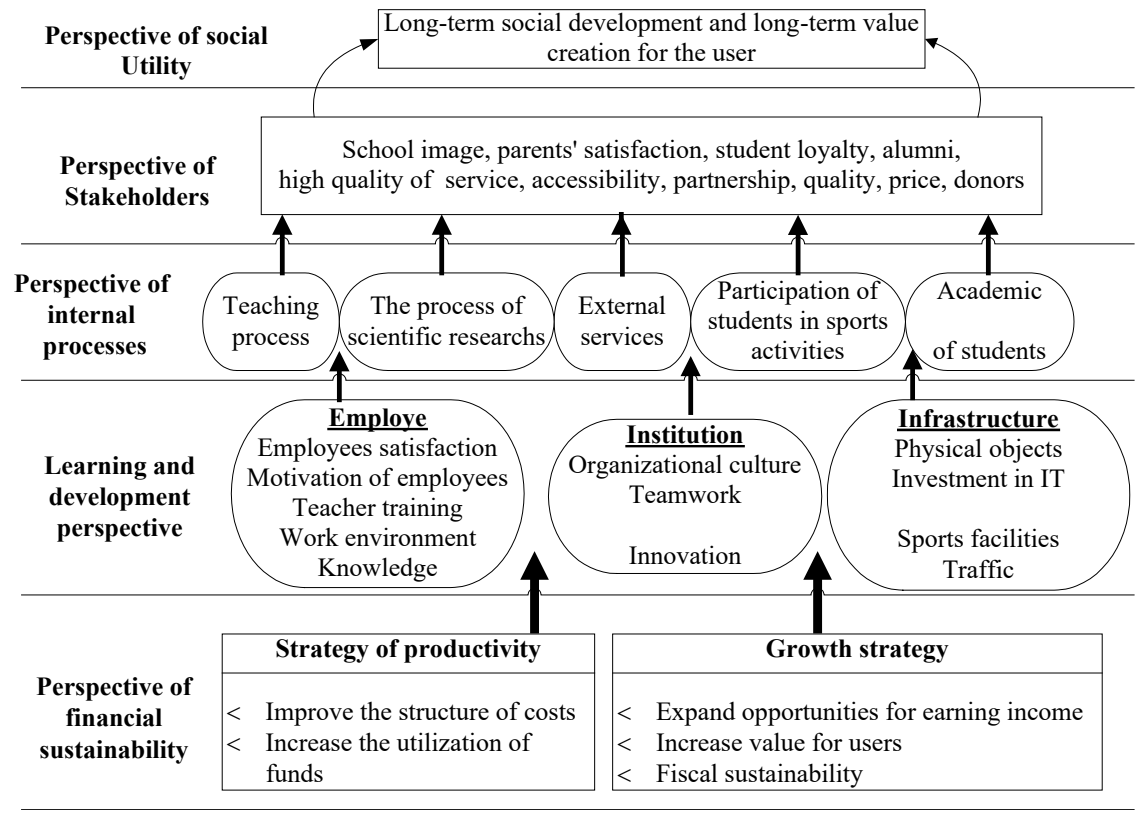

Source: Binden Worawit, Mziu Hajdar, Suhaimi Mohd Adam (2014), 40-42.; Pietrzak Michal (2014), 34-37.; Umashankar Venkatesh, Dutta Kirti (2007), 62-64.; Visalakshi, S. (2016), 36., 368. Yüksel Harun, Coskun Ali (2013), 2458.;

\footnotetext{
$36 \quad$ Jaško Ondrej, et al. (2013), 379.

37 Jaško Ondrej, et al. (2013), 380.
} 
The indicators within the financial perspective are indicators of results, while indicators in other perspectives give signals and point to the need to implement corrective measures ${ }^{38}$.

Performance indicators can be defined and used for different purposes at the level of the higher education institution, but also at the education system level. Performance indicators at the national level can be designed for a number of reasons: ensuring accountability for state funds, improving the quality of higher education, stimulating competition within and between institutions, verifying (confirming) the quality of new institutions, assigning institutional status, securing the transfer of competencies between the state and institutions, and Facilitating comparisons at the international level ${ }^{39}$.

\subsection{Application of Balanced Scorecard in higher education institutions in Serbia}

In the previous chapter, the BSC is defined and it is indicated on the possibilities of its application in higher education institutions based on the performed analysis of secondary sources and on the basis of the practice that exists in higher education institutions of educational systems of other countries. The state of development and application of BSC in higher education institutions in our region is not at an enviable level. However, by adopting the Bologna Process, the Law on Higher Education and the adoption of other documents at the national level, the basis for the establishment and implementation of the BSC in our territories can be recognized.

The Government of the Republic of Serbia adopted, in October 2012, a Strategy for the Development of Education in Serbia until 2020. Within the strategy are defined strategic commitments, actions leading to the implementation of the strategy and indicators through which the success of these actions will be monitored ${ }^{40}$.

Since each strategy should be accompanied by an action plan, in February 2015, the Action Plan for Implementation of the Strategy for the Development of Education in Serbia was adopted by 2020. The Action Plan specifies individual activities (actions) defined by the objectives and priorities of the Strategy, elaborated ways of implementation, deadlines, key bearers and executors, monitoring instruments and indicators (indicators) of progress, as well as the procedures for reporting and assessing the effects of the planned strategic measures ${ }^{41}$.

38 Vanderbeck J.Edward (2014), Principles of Cost Accounting, South - Western Cengage Learning, $15^{\text {th }}$ Edition.463.

39 Cave Martin et al. (1997): The Use of Performance Indicators in Higher Education: The Challenge of the Quality Movement (3rd ed.). London: Jessica Kingsley.44.

40 Strategija razvoja obrazovanja u Srbiji do 2020. godine. Službeni glasnik Republike Srbije. Broj 107/2012. od 9.11.2012. godine.

41 Akcioni plan za sprovođenje Strategije razvoja obrazovanja u Srbiji do 2020. godine. Službeni glasnik Rebublike Srbije. Broj 16. od 9.02.2015. godine. 
According to the report of the World Economic Forum since 2015, Serbia recorded the global competitiveness index of 3.9, which ranks it in $94^{\text {th }}$ place on the list that includes 144 countries. And in 2016, Serbia ranked $94^{\text {th }}$ in the ranking of the World Economic Forum, out of a total of 140 ranked countries, meaning it retained its position.

The World Economic Forum Global Competitiveness Report ranks Serbia's competitiveness in $78^{\text {th }}$ place out of a total 137 countries (GCR, 2017-2018).

Regarding higher education and training, Serbia in 2015, as well as in 2016, recorded a global competitiveness index of 4.3. Indicators monitored within higher education are:

- quantity / number of educated (rates enrolled in secondary education, enrollment in higher education),

- the quality of higher education (the quality of the education system in terms of meeting the needs of a competitive economy, the quality of mathematics and natural sciences, the quality of management schools, the degree of use of internships in schools for the purpose of learning)

- workplace training (local availability of professional training services, amount of investment in staff training).

Indicators monitored globally, i.e. at the World Economic Forum, as one of the most important forums, can be translated into indicators that would be monitored at the level of one state in order to monitor the performance of the education system, and even the indicators that would be applied at the level of individual higher education institutions.

Observing global-level indicators for the purpose of country ranking, each can associate with a certain perspective of the BSC. The quantity, or number of educated, can be linked to the perspective of stakeholders and with the indicators in Table 1 related to the number of students enrolled and degree of remaining at the institution.

The quality of higher education can also be linked to the perspective of internal processes, and the financial perspective and perspective of learning and development. In case of considering education as one system, its quality is influenced by all three perspectives.

Training as an indicator can be classified in the perspective of learning and development, as well as to connect with the indicators in Table 1 the number of visits seminars (conferences), the number of presentations by the institution by conferences, the number of attended seminars, the number of published works, the number of projects and number of workshops attended by the institution. Exactly this indicator records the lowest global competitiveness index: the volume of investments in staff training (3.0) and the quality of the education system (3.1). 
Table 1: Balanced Scorecard for education service

\begin{tabular}{|c|c|c|c|}
\hline \multicolumn{2}{|l|}{ Perspective } & Goal & $\begin{array}{l}\text { Indicator or measure of } \\
\text { performance }\end{array}$ \\
\hline \multirow{21}{*}{$\begin{array}{l}\text { Perspective of } \\
\text { stakeholders }\end{array}$} & \multirow{7}{*}{ Students } & \multirow{2}{*}{ To attract quality students } & Number of received / registered \\
\hline & & & Number of rejected students \\
\hline & & Loyality & Degree of leaving studies \\
\hline & & Encouraging cultural, sporting and & Number of participation in the event \\
\hline & & social activities & Students satisfaction level \\
\hline & & Effectiveness of employment of & $\begin{array}{l}\text { Percentage of employment of students } \\
\text { before graduation }\end{array}$ \\
\hline & & students & $\begin{array}{l}\text { Number of engaging students from the } \\
\text { campus }\end{array}$ \\
\hline & \multirow[b]{2}{*}{ Alumni } & Increase alumni satisfaction & A number of engaged alumni \\
\hline & & $\begin{array}{l}\text { Possibility of upgrading knowledge } \\
\text { over time }\end{array}$ & Feedback from the alumni \\
\hline & \multirow{5}{*}{ Employers } & \multirow{5}{*}{ Employers' satisfaction } & Job Offers \\
\hline & & & The ability of graduates to progress \\
\hline & & & $\begin{array}{l}\text { Researching and evaluating employers } \\
\text { about the quality of graduates }\end{array}$ \\
\hline & & & Number of scholarships \\
\hline & & & Average offered earnings \\
\hline & \multirow{3}{*}{ Comunity } & $\begin{array}{l}\text { Developing a way of cooperating } \\
\text { and supporting institutions }\end{array}$ & \multirow{2}{*}{$\begin{array}{l}\text { Number of conducted studies and } \\
\text { provided services in this regard }\end{array}$} \\
\hline & & $\begin{array}{l}\text { Encouraging the participation of } \\
\text { teaching staff in state and public } \\
\text { organizations }\end{array}$ & \\
\hline & & $\begin{array}{l}\text { Encouraging partnerships with } \\
\text { affiliated institutions }\end{array}$ & Jointly projects \\
\hline & \multirow{4}{*}{ Employees } & \multirow{4}{*}{$\begin{array}{l}\text { Learning and development } \\
\text { opportunities }\end{array}$} & $\begin{array}{l}\text { Growth in earnings over a certain } \\
\text { period }\end{array}$ \\
\hline & & & \begin{tabular}{|l|}
$\begin{array}{l}\text { Completed courses and other } \\
\text { educational programs }\end{array}$ \\
\end{tabular} \\
\hline & & & \begin{tabular}{|l} 
Knowledge and skills acquired \\
through work assignments \\
\end{tabular} \\
\hline & & & Welfare of employees \\
\hline \multirow{5}{*}{\multicolumn{2}{|c|}{ Financial perspective }} & $\begin{array}{l}\text { Improving the self-financing of a } \\
\text { higher education institution }\end{array}$ & $\begin{array}{l}\text { Number or percent increase in fund } \\
\text { revenue }\end{array}$ \\
\hline & & Improve cost structure & Savings on service costs \\
\hline & & Increase the utilization of resources & Efficient use of facilities and resources \\
\hline & & \multirow{2}{*}{ Expand revenue opportunities } & Enrollment level (trend) \\
\hline & & & Stakeholders donations \\
\hline \multirow{3}{*}{\multicolumn{2}{|c|}{$\begin{array}{l}\text { The perspective of the internal } \\
\text { process }\end{array}$}} & $\begin{array}{l}\text { Development of study programs at } \\
\text { all levels of study }\end{array}$ & \begin{tabular}{|l}
$\begin{array}{l}\text { Number of adopted (accredited) } \\
\text { programs }\end{array}$ \\
\end{tabular} \\
\hline & & $\begin{array}{l}\text { Signing partnerships with other } \\
\text { universities in order to provide joint } \\
\text { or double diplomas }\end{array}$ & Number of signed contracts \\
\hline & & $\begin{array}{l}\text { Attracting foreign teaching staff } \\
\text { and experts from national and } \\
\text { international bodies }\end{array}$ & Number of staff \\
\hline
\end{tabular}




\begin{tabular}{|c|c|c|}
\hline Perspective & Goal & $\begin{array}{l}\text { Indicator or measure of } \\
\text { performance }\end{array}$ \\
\hline \multirow{4}{*}{$\begin{array}{l}\text { The perspective of the internal } \\
\text { process }\end{array}$} & $\begin{array}{l}\text { Improving the academic } \\
\text { performance of students }\end{array}$ & Results of the students for the exam \\
\hline & Improving teachers' skills & Spent funds for teachers' development \\
\hline & $\begin{array}{l}\text { Increasing the participation of } \\
\text { students in sports activities }\end{array}$ & Number of students' participation \\
\hline & Development of training programs & Number of programs available \\
\hline \multirow{15}{*}{$\begin{array}{l}\text { The persective of learning and } \\
\text { development }\end{array}$} & \multirow{3}{*}{$\begin{array}{l}\text { Professional development of the } \\
\text { institution }\end{array}$} & $\begin{array}{l}\text { Abstract budget for attendance at } \\
\text { conferences }\end{array}$ \\
\hline & & $\begin{array}{l}\text { A number of visits, seminars } \\
\text { (conference) }\end{array}$ \\
\hline & & $\begin{array}{l}\text { Number of presentations of the } \\
\text { institution from conferences }\end{array}$ \\
\hline & Improving employee satisfaction & $\begin{array}{l}\text { A satisfaction report based on the } \\
\text { survey }\end{array}$ \\
\hline & Implementation of technologies & $\begin{array}{l}\text { Number of courses in the application } \\
\text { of new technologies }\end{array}$ \\
\hline & Increasing knowledge & A number of seminars attended \\
\hline & Supporting scientific research work & $\begin{array}{l}\text { The number of holding seminars } \\
\text { based on raising awareness about } \\
\text { how to publish works in international } \\
\text { journals }\end{array}$ \\
\hline & $\begin{array}{l}\text { Encouraging the publication of } \\
\text { works in international journals }\end{array}$ & Number of published works \\
\hline & $\begin{array}{l}\text { Communicating with donors for } \\
\text { scientific research work }\end{array}$ & Number of donations signed \\
\hline & $\begin{array}{l}\text { Improving the quality of library } \\
\text { services }\end{array}$ & Student's satisfaction level \\
\hline & $\begin{array}{l}\text { Development of a student safety and } \\
\text { security system }\end{array}$ & Established system \\
\hline & $\begin{array}{l}\text { Improving the quality of sports } \\
\text { facilities }\end{array}$ & Satisfaction level of students \\
\hline & $\begin{array}{l}\text { Ensure and encourage the } \\
\text { development of a comfortable } \\
\text { operating environment with } \\
\text { modern equipment }\end{array}$ & $\begin{array}{l}\text { Level of satisfaction of teaching and } \\
\text { non-teaching staff }\end{array}$ \\
\hline & $\begin{array}{l}\begin{array}{l}\text { Partnership with business } \\
\text { organizations }\end{array} \\
\end{array}$ & Number of reached partnerships \\
\hline & Resource management & Trends in using energy \\
\hline $\begin{array}{l}\text { The persective of learning and } \\
\text { development }\end{array}$ & Innovation in teaching & $\begin{array}{l}\text { Number of projects and number of } \\
\text { workshops attended by the institution }\end{array}$ \\
\hline
\end{tabular}

Source: Binden Worawit, Mziu Hajdar, Suhaimi Mohd Adam (2014), 40-42.; Pietrzak Michal (2014), 34-37.; Umashankar Venkatesh, Dutta Kirti (2007), 62-64.; Visalakshi, S. (2016), 36., 368.; Yüksel Harun, Coskun Ali (2013), 2458.;

Looking from the perspective of competitiveness, Serbia needs to improve the competitive ability of its economy, which is at a low level, and one of the consequences is the quality of the education system, but also the poor financial possibilities for conducting training and development. 
Higher education institutions define performance indicators for four basic reasons: to monitor their performance for comparison, to facilitate the evaluation of the activities of the institution, to provide information on the quality of external auditors, to provide information on accountability and fulfillment of its purpose for the government ${ }^{42}$.

In accordance with the previous, as well as on the basis of the observed practice of applying the BSC and based on the analyzed literature, in Table 1, is given a proposal of objectives and performance indicators for each of the perspectives at the level of higher education institutions that could be used for the purpose of monitoring and measuring the perfomance of higher education institutions in Serbia.

Some indicators can also be identified on the ARWU Shanghai List as one of the most popular methodologies used for ranking universities and are based on six indicators ${ }^{43}$.

From the point of view of the higher education system in Serbia, it can be said that the key basis for defining the performance indicators of the HEI have already been developed. These basis primarily relates to the Law on Higher Education, standards for accreditation of the Higher School of Arts, standards for accreditation of study programs, standards for self-evaluation and evaluation of the quality of the school.

If we take into account the fact that the Bologna process is accepted, and that all higher education institutions in Serbia have passed the accreditation process, and then re-accreditation, as well as applying the appropriate standards for quality assurance, it can be said that there are necessary conditions for the implementation and implementation of the BSC as a strategic management system for a higher education institution.

Taking into account the previous, there are no restrictions in the form of an appropriate background in performance management in higher education institutions using the BSC. There may be financial constraints, as software for the application of this system requires significant financial resources. In addition to this limitation, there is certainly resistance to change as something that is characteristic of all social groups, and perhaps a certain degree of fear that the level of quality of a higher education institution and its reputation on the basis of achieved performance will be revealed.

$42 \quad$ Chalmers Denise (2008, September):. Teaching and learning quality indicators in Australian universities. IMHE-2008, Programme on Institutional Management in Higher Education. Paris, France. 3.

43 Jeremić Veljko (2012): Statistički model efikasnosti zasnovan na Ivanovićevom odstojanju. Fakultet organizacionih nauka. Beogad. (PHD dissertation).79-81. 


\section{Conclusion}

Defining Performance Indicators through four perspectives of the BSC, as well as monitoring and measuring them in an adequate way, provides a strong potential in the process of assessing the quality of higher education institutions. A set of indicators, identified through the four perspectives of the BSC to be monitored and measured in higher education institutions, would allow comparison of universities and higher education institutions, which is one of the recommendations of the Bologna Declaration.

Consideration of application of possibilities and gradual establishment of the BSC should be one of the basic goals of higher education institutions. Research in this paper pointed to the presence of performance indicators of higher education institutions in the education system of Serbia by defining them through the documents of the National Council for Higher Education, Ministry of Education, Science and Technological Development, the Commission for Accreditation and Quality Assurance (National Accreditation Body), but it may only be necessary to improve in terms of their uniformity, universality and promoting the application of the BSC for these purposes.

However, the application of this system in higher education institutions, on the one hand, restricts the financial situation that is characteristic of countries such as Serbia, and on the other hand, and insufficiently competent staff that would deal only with quality and definition of indicators on a daily basis and their monitoring and measurement. An additional limiting factor in the application of the BSC is the lack of adequate information support.

The benefit of applying such a single system to the High School Institutions can be triple. For the institution itself, in terms of balanced management of processes and resources, for the state from the aspect of monitoring the goals defined by the HEI, and for the users i.e., students in terms of making decision on the selection of the High School Institutions.

\section{Literature}

- Adizes Isak (2015): Managing Corporate Lifeycles - Part 2. Santa Barbara, CA: The Adizes Institute Publications.

- Akcioni plan za sprovođenje Strategije razvoja obrazovanja u Srbiji do 2020. godine. Službeni glasnik Republike Srbije. Broj 16.of 9.02.2015. godine.

- Al-Zwyalif M. Inaam (2017): Using a Balanced Scorecard Approach to Measure Environmental Performance: A Proposed Model. International Journal of Economics and Finance. Vol. 9, No. 8. 118-126.

- Binden Worawit, Mziu Hajdar, Suhaimi Mohd Adam (2014):. Employing the Balanced Scorecard (BSC) to Measure Performance in Higher Education - 
Malaysia. International Journal of Information and Communication Technology Research, 4(1). 38-44.

- Cave Martin et al. (1997): The Use of Performance Indicators in Higher Education: The Challenge of the Quality Movement (3rd ed.). London: Jessica Kingsley.

- Chalaris Ioannis, Chalaris Manolis, Gritzalis Stefanos (2014): A holistic approach for quality assurance and advanced decision making for academic institutions using the balanced scorecard technique. PDI 14 - Proceedings of the 18th Panhellenic Conference on Informatics. 1-6.

- Chalmers Denise (2008): Teaching and learning quality indicators in Australian universities. IMHE-2008, Programme on Institutional Management in Higher Education. Paris, France. 2-18.

- Chen S. Al Yuang, Beasley Mark, Nunez Karon (2006): Working Hand in Hand: Balanced Scorecard and Enterprise Risk Management. Strategic Finance. 49-55.

- Deshpande Bharati (2015): Application of Balanced Score Card in Higher Education with special emphasis in a Business School. International Conference on Technology and Business Management. 201-205.

- Domanović Violeta, Bogićević Jasmina, Savović Sladjana (2012): Problems and Perspectives of Balanced Scorecard Implementation in Serbia. African Journal of Business Management. Vol. 6(23), 6818-6831.

- Eftimov Ljupco et al. (2016): Designing a Balanced Scorecard as Strategic Management System for Higher Education Institutions: A Case Study in Macedonia. Ekonomika: Vol. 62. No. 2. 29-48.

- Gao Hongda, et al. (2018): Balanced scorecard-based performance evaluation of Chinese county hospitals in underdeveloped areas. Journal of International Medical Research. Vol. 46(5). 1947-1962.

- Geuser D. Fabien, Mooraj Stella, Oyon Daniel (2009): Does the Balanced Scorecard Add Value? Empirical Evidence on its Effect on Performance. European Accounting Review. Vol. 18. No. 1. 93-122.

- Indeks globalne konkurentnosti. World Economic Forum - Davos 2016. http://reports.weforum.org/global-competitiveness-report-2015-2016/econo mies/\#indexId=GCI\&economy=SRB (pristupljeno 11.02.2017)

- Jaško Ondrej, et al. (2013): Projektovanje organizacije. Beograd. Fakultet organizacionih nauka.

- Jeremić Veljko (2012): Statistički model efikasnosti zasnovan na Ivanovićevom odstojanju. Fakultet organizacionih nauka. Beograd. (PHD dissertation).

- Jovanović Petar (2007): Strategijski menadzment. Beograd. Fakultet organizacionih nauka.

- Kalender T. Zeynep (2016): The Fifth Pillar of the Balanced Scorecard: Sustainability. Procedia - Social and Behavioral Sciences.Vol. 235. (24).76-83. 
- Kaplan S. Robert, Norton P.David (1992): The Balanced Scorecard - Measures that Drive Performance. Harvard Business Review.

- Kaplan S. Robert, Norton P.David (1993): Putting the Balanced Scorecard to Work, Harvard Bussiness Review.

- Kaplan S. Robert, Norton P.David (1996): The Balanced Scorecard: Translating Strategy into Action. Harvard Business School Press, Boston, Massachusetts.

- Manica Edson, et al. (2017): Deployment of the Balanced Scorecard as A Tool for Measuring Performance: The Case of A Technology Company in Brazil. Business Management Dynamics. Vol.7. No.6. 8-18.

- Pietrzak Michal (2014): Using the strategy map as a strategic communication tool in higher education: A case study of Warsaw University of Life Sciences. Online Journal of Applied Knowledge Management, Vol. 2(2), 26-42.

- Pietrzak Michail, Paliszkiewicz Joanna, Klepački Bogdan (2015): The application of the balanced scorecard (BSC) in the higher education setting of a Polish university. Online Journal of Applied Knowledge Management. 3(1), 151-164.

- Pimentel Luis, Major J. Maria (2014): Quality management and a balanced scorecard as supporting frameworks for a new management model and organisational change. Total Quality Management. 25( 7). 763-775.

- Pravdić Predrag (2011): Spreading BSC Idea and Technology in Serbia. 38. Nacionalna konferencija o kvalitetu. Festival kvaliteta - FQ2011. 21-28.

- Stevanović Tatjana, Petrović - Randjelović Marija (2012): Sustainability Balanced Scorecard and Eco-efficiency Analysis. Economics and Organization. Vol 9. No 2. 257-270.

- Strategija razvoja obrazovanja u Srbiji do 2020. godine. (2012). Službeni glasnik Republike Srbije. Broj 107/2012. od 9.11.2012. godine.

- Sudirman Indrianty (2012): Implementing Balanced Scorecard in Higher Education Management. Case Study: Hasanuddin University of Indonesia. International Journal of Business and Social Science, Vol.3 No.18. 199-204.

- Sulanjaku Marsel (2014): The Perspecives of Using Balanced Scorecard in Intangibles Measurement and Management in Albania. International Journal of Managerial Studies and Research. Vol 2. No 9. 132-139.

- Sustainbality Balanced Scorecard, BSC Designer. https://bscdesigner.com/ sustainability-balanced-scorecard-sbsc.htm (pristupljeno 17.06.2018.)

- Sweiti M. Ibrahim, Lele Upendra (2016): Impact of Balanced Scorecard Implementation on Financial Performance of Saudi Listed Companies. Journal of Behavioural Economics, Finance, Entrepreneurship, Accounting and Transport. Vol. 4. No. 1. 8-12.

- The Global Competitiveness Report 2017-2018. World Economic Forum. http://www3.weforum.org/docs/GCR2017-2018/05FullReport/TheGlobalCo mpetitivenessReport2017\%E2\%80\%932018.pdf (pristupljeno 25.06.2018.) 
- Todorovic Miroslav, Kaličanin Djordje, Nojković Aleksandar (2015): Prakse merenja performansi u preduzećima u Republici Srbiji. Ekonomski horizonti. Vol. 17. (1). 45-59.

- Tornjanski Vesna, Knežević Snežana, Delibašić Boris (2016): A CRM Performance Measurement in Banking Using Integrated BSC and Customized ANP-BOCR Approach. Management: Journal of Sustainable Business and Management Solutions in Emerging Economies. Vol. 22. No.1. 71-85.

- Umashankar Venkatesh, Dutta, Kirti (2007): Balanced Scorecards in managing higher education institutions: an Indian perspective. International Journal of Education Management, 21(1). 54-67.

- Vanderbeck J.Edward (2014): Principles of Cost Accounting, South - Western Cengage Learning, $15^{\text {th }}$ Edition.

- Visalakshi S. (2016). Performance measurement of Commercial Banks in India using Balanced Scorecard. School of Management. Pondicherry University. Pondicherry. ( $\mathrm{PhD}$ thesis).

- Wahba Mohamed (2016): Balanced Scorecard in Higher Education Applied case study on "Arab Academy for Science, Technology and Maritime Transfer. International Journal of Scientific Research and Innovative Technology, 3(5). 69-91.

- Yüksel Harun, Coskun Ali (2013): Strategy focused schools: an implementation of the balanced scorecar in provision of educational services. Procedia - Social and Behavioral Sciences. Vol.106. 2450-2459.

- Zeng Kaisheng, Luo Xiaohui (2013): The Balanced Scorecard in China: Does it work? Business Horizons. 56. 611-620 
Pregledni naučni članak Primljen 29.04.2019. Odobren 26.07.2019.

\section{INDIKATORI PERFORMANSI I MOGUĆNOSTI PRIMENE BALANCED SCORECARD-A U VISOKOŠKOLSKIM USTANOVAMA}

Primenom eksplorativnog $i$ deskriptivnog istraživanja u radu se ukazuje na značaj $i$ mogućnost primene Balanced Scorecard-a u visokoškolskim ustanovama. Cilj rada je ukazivanje na dobru praksu primene Balanced Scorecard-a u visokom obrazovanju $i$ predlaganje indikatora performansi za svaku od perspektiva na nivou visokoškolske ustanove, koji bi mogli da se primenjuju u svrhu praćenja i merenja performansi visokoškolskih ustanova u Srbiji. Predloženi indikatori su opšteg karaktera i mogu se primeniti u bilo kojoj visokoškolskoj ustanovi, naročito u zemljama u razvoju u kontekstu reformi i razvoja sistema visokog obrazovanja. Rezultati istraživanja ukazuju na prisutnost indikatora performansi visokoškolskih ustanova u obrazovnom sistemu Srbije. Mogu se prepoznati u dokumentima na nacionalnom nivou. Potrebno ih je samo poboljšati u smislu njihove jednoobraznosti i univerzalnosti.

Ključne reči: Balanced Scorecard, indikatori performansi, visokoškolska ustanova, strategija. 